\title{
Pengukuran Modulus Young dengan Analisis Keadaan Resonansi Batang Aluminium yang Bergetar Menggunakan ImageMeter
}

\author{
Maria Tefa, Ign Edi Santosa \\ Program Studi Pendidikan Fisika, Universitas Sanata Dharma Yogyakarta \\ Paingan, Maguwoharjo, Depok, Sleman, Yogyakarta \\ Email: mariatefa13@gmail.com, edi@dosen.usd.ac.id
}

\begin{abstract}
An experiment to determine Young's Modulus by analyzing the vibrations of an aluminum bar has been conducted. The aluminium bar is vibrated by the magnetic field. A tiny magnet is glued at the free end of the bar. A coil carrying an alternating current generates an alternating magnetic field. The resonance condition is investigated by the measurement of its wavelength using the ImageMeter application. The natural frequency of the aluminum bar is determined from the measurement of its resonance frequencies. The natural frequency and the bar length are used to calculate Young's Modulus. The experimental data shows the Young's Modulus of aluminum is $Y=(5,04 \pm 0,03) \times 10^{10} \mathrm{~N} / \mathrm{m}^{2}$. This measurement method is used for learning purposes.
\end{abstract}

Keywords: Young's Modulus, resonance, natural frecuency, ImageMeter

\begin{abstract}
Abstrak: Telah dilakukan pengukuran nilai Modulus Young dengan analisis getaran dari sebuah batang aluminium. Batang aluminium digetarkan dengan medan magnet. Magnet kecil ditempelkan pada bagian ujung batang aluminium yang bebas. Sebuah kumparan yang berada di bawah ujung batang aluminium diberi arus bolak balik yang dapat diatur frekuensinya. Pada frekuensi tertentu akan terjadi resonansi dengan mengikuti pola yang khas. Keadaan resonansi batang aluminium ini dibuktikan dari hasil pengukuran panjang $\lambda$ menggunakan aplikasi ImageMeter. Selanjutnya frekuensi alami batang aluminium ditentukan dari pengukuran frekuensi resonansinya. Nilai Modulus Young aluminium dihitung dari nilai frekuensi alami dan panjang batang. Dari hasil pengukuran diperoleh nilai Modulus Young $Y=(5,04 \pm 0,03) \times 10^{10} \mathrm{~N} / \mathrm{m}^{2}$. Metoda pengukuran ini digunakan untuk keperluan pembelajaran.
\end{abstract}

Kata kunci: Modulus Young, resonansi, frekuensi alami, ImageMeter

\section{PENDAHULUAN}

Modulus Young merupakan salah satu nilai elastisitas yang menyatakan resistansi suatu benda padat terhadap perubahan panjang yang dialaminya. Nilai Modulus Young sebuah bahan di dunia industri menjadi suatu hal yang penting untuk diketahui. Salah satunya berkaitan dengan pemilihan bahan yang tepat untuk pemanfaatannya sebagai produk perkembangan teknologi dalam hidup keseharian.

Pengukuran untuk menentukan nilai Modulus Young suatu bahan dalam pembelajaran masih kurang. Pengukuran Modulus Young yang pernah dilakukan yaitu dengan mengamati pertambahan panjang kawat ketika kawat ditarik dengan sebuah gaya [Murray, 1982]. Gaya diberikan dengan cara memberi beban pada ujung kawat. Metode yang digunakan tersebut memiliki kelemahan dapat merusak kawat apabila beban yang ditambahkan tidak dikontrol dan melebihi batas elastisitas kawat.

Pengukuran Modulus Young stainless steel dengan analisis dapat mengurangi potensi kerusakan bahan akibat pemberian tegangan berupa beban yang ditambahkan yang melebihi batas elastisitas. Dalam pengukuran dengan analisis getaran, regangan yang terjadi kecil sehingga hubungan antara tegangan tarik dan regangan tarik tidak melewati batas elastisitas. 
Pengukuran ini menggunakan Force Sensor untuk mengukur frekuensi alami dari batang stainless steel. Hasil pengukuran ditampilkan dalam grafik hubungan antara gaya dengan waktu dalam program logger pro kemudian diubah ke grafik Fast Fourier Transform (FFT) untuk mendapat nilai frekuensi alami getaran tersebut [Sahu, 2017]. Pengukuran frekuensi alami dilakukan secara tidak langsung dengan Force Sensor. Perangkat pengukuran yang digunakan terdiri dari sensor dan interface, harganya relatif mahal. Selain itu getaran yang terjadi pada batang stainless steel dapat teramati dalam waktu yang sangat singkat karena adanya redaman.

Penelitian lain untuk menentukan nilai Modulus Young aluminium dengan analisis getaran, dilakukan dengan menggetarkan batang aluminium secara elektrik dengan bantuan magnet kecil yang ditempelkan di salah satu ujungnya. Kemudian bagian ujung batang aluminium tersebut ditempatkan di atas sebuah kumparan yang dialiri arus listrik bolak balik dengan frekuensi yang dapat diatur. Pada saat frekuensi medan magnet sama dengan frekuensi alami sistem (batang aluminium dan magnet) maka akan terjadi resonansi. Frekuensi alami batang aluminium pada keadaan tidak ada beban magnet yang ditambahkan dapat ditentukan dari grafik frekuensi resonansi terhadap massa magnet yang ditambahkan pada ujung batang aluminium yang bebas [Pradan, R. et al, 2015]. Nilai Modulus Young ditentukan dari hasil nilai frekuensi pada saat resonansi. Namun pada penelitian ini penentuan keadaan resonansinya tidak ditampilkan.

Untuk itu pada penelitian ini Modulus Young aluminium akan ditentukan dari pengukuran frekuensi alami dengan pengecekan keadaan resonansinya terlebih dahulu. Pengecekan dilakukan dengan mengamati pola getaran yang direkam dengan kamera. Analisa foto semacam ini sudah digunakan untuk berbagai penelitian. Aplikasi foto analyzer digunakan untuk mengukur jari-jari sebuah pipa plastik karena pengukuran secara langsung menggunakan jangka sorong dapat merubah bentuk objek yang diukur. Foto analyzer membantu proses pengukuran suatu objek yang tidak dapat diukur secara langsung [Apriati, 2017].

Pada penelitian ini penentuan nilai Modulus Young aluminium dilakukan dengan analisis keadaan resonansi menggunakan aplikasi ImageMeter. Alat dan bahan yang digunakan sederhana dan mudah diperoleh di laboratorium. Rangkaian alat, prosedur percobaan, dan pengamatan eksperimen sederhana dan tidak memerlukan alat bantu khusus seperti sensor dan lainnya. Analisis data pun cukup menggunakan aplikasi Logger Pro dan Image Meter sehingga tidak menyulitkan bagi siswa untuk pembelajaran.

Eksperimen dengan analisis getaran batang aluminium juga dapat menunjukkan berbagai konsep fisika yaitu getaran paksa, gelombang, resonansi, kelistrikkan dan kemagnetan dalam suatu kegiatan pengukuran Modulus Young aluminium. Keterkaitan antara satu konsep dengan konsep yang lain pun dapat dijelaskan dalam kegiatan pengukuran tersebut. Oleh karena itu, penelitian ini bisa menjadi acuan metode pembelajaran fisika konstruktivisme dan sebagai contoh pengajaran berbagai konsep dalam suatu peristiwa fisika.

\section{METODE PENELITIAN}

Batang aluminium yang digunakan adalah sebuah batang aluminium berbentuk balok tipis dengan panjang $l$, tebal $d$, dan massa jenis $\rho$. Syarat yang harus dipenuhi oleh batang aluminium yang digunakan untuk dianalisis getarannya menurut teori Euler-Bernoulli adalah panjangnya jauh lebih besar dari pada tebalnya (lebih dari 10 kali) [Rao, 2007]. Salah satu ujung batang aluminium tersebut dijepitkan pada sebuah meja, sedangkan ujung yang lainnya dibiarkan bebas,sehingga memungkinkan bagian yang bebas tersebut dapat bergetar secara vertikal. 
Frekuensi natural untuk getaran sebuah batang aluminium yang seragam mengikuti persamaan Euler getaran lateral balok, yaitu [Thomson, 1992]:

$$
f_{n}=\left(\beta_{n} / l\right)^{2} \cdot\left(Y d^{2} /\left(12 \rho \cdot 4 \pi^{2}\right)\right)^{1 / 2}
$$

dengan

$$
\begin{array}{ll}
\beta_{n} & : \text { nilai numerik ke-n } \\
Y & : \text { Modulus Young } \\
l & \text { : panjang batang aluminium } \\
d & : \text { tebal aluminium } \\
\rho & : \text { massa jenis aluminium } \\
f_{n} & : \text { frekuensi alami getaran harmonik ke-n }
\end{array}
$$

Nilai $\beta_{n}$ berturut-turut untuk keadaan harmonik pertama, harmonik kedua, dan harmonik ketiga adalah $\beta_{1} \approx 1,9 ; \beta_{2} \approx 4,7 ; \beta_{3} \approx 7.9$.

Keadaan resonansi yang terjadi pada batang aluminium mengikuti bentuk lenturan pada batang cantilever yang bergetar menurut Euler-Bernoulli seperti yang ditunjukkan pada gambar 1 [Rao, 2007].

a) $f_{1}$

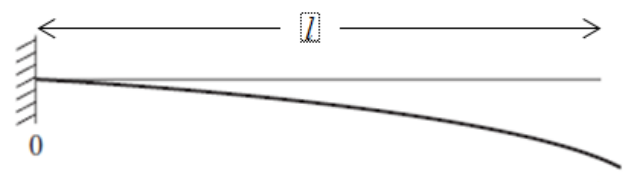

b) $f_{2}$

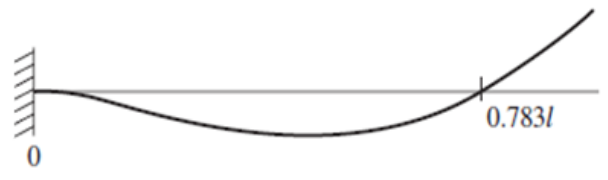

c) $f_{3}$

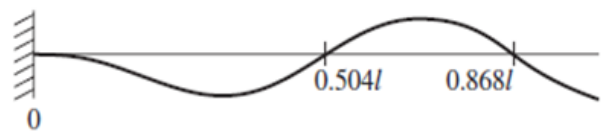

d) $f_{4}$

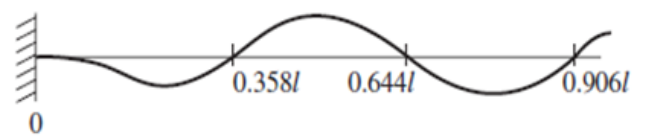

Gambar 1 Bentuk lenturan batang cantilever yang bergetar untuk empat frekuensi menurut Euler Bernouli

Berdasarkan gambar 1, keadaan resonansi untuk setiap frekuensi ditandai dengan panjang $\lambda$ yang dihasilkan.

Keadaan untuk $f_{l}$, berlaku:

Keadaan untuk $f_{2}$, berlaku:

$$
\begin{aligned}
& \lambda=4 l \\
& \lambda=1,6 l
\end{aligned}
$$

Keadaan untuk $f_{3}$, berlaku:

$$
\lambda=0,87 l
$$


Keadaan untuk $f_{4}$, berlaku:

$$
\lambda=0,64 l
$$

Susunan alat pada eksperimen ini disajkan pada gambar 2.

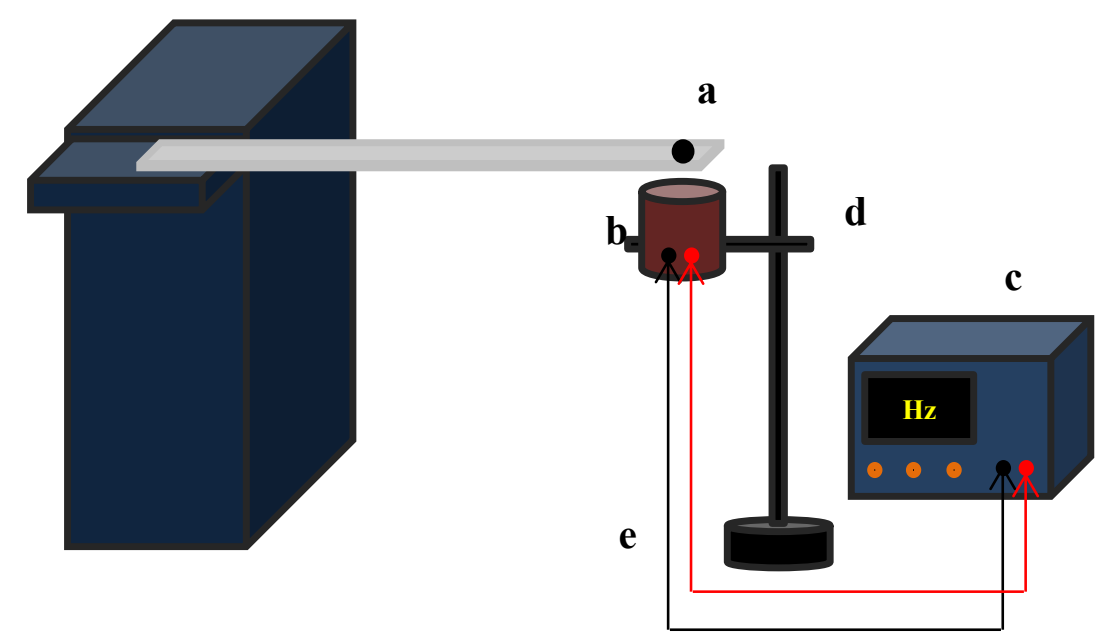

Gambar 2 Rangkaian alat untuk pengukuran frekuensi resonansi getaran batang aluminium

Keterangan gambar:

a: batang aluminium dengan magnet ditempelkan pada salah satu

ujungnya

b: Kumparan

c: Audio Frecuency Generator (AFG)

d: Statif

e: kabel penghubung

Pada eksperimen batang aluminium digetarkan secara magnetik dengan bantuan magnet kecil yang dilekatkan pada ujung bagian batang yang bebas. Kemudian bagian batang yang bebas tersebut diletakkan di sebuah medan magnet yang berubah terhadap waktu. Ketika frekuensi medan magnet sama dengan frekuensi alami sistem (aluminium dan magnet) maka akan terjadi resonansi. Resonansi yang terjadi ditandai dengan terbentuknya gelombang seperti pada gambar 1. Untuk membuktikan keadaan resonansi tersebut, selain dengan membandingkan bentuk yang terbentuk dengan gambar 1, dilakukan pengukuran panjang gelombang yang dihasilkan dari getaran batang aluminium dengan aplikasi ImageMeter.

Pengukuran frekuensi resonansi dilakukan untuk batang aluminium dengan panjang $0,3 \mathrm{~m}$, $0,35 \mathrm{~m}, 0,4 \mathrm{~m}, 0,45 \mathrm{~m}$, dan $0,5 \mathrm{~m}$. Untuk satu panjang $l$ dilakukan variasi massa magnet yang ditambahkan. Pengukuran dilakukan sebanyak enam kali.

Frekuensi alami batang aluminium yaitu frekuensi saat tidak ada magnet yang ditambahkan ditentukan dari grafik hubungan antara frekuensi resonansi dengan massa magnet yang ditambahkan. Frekuensi alami aluminium didapatkan dari perpotongan grafik dengan sumbu tegak. Selanjutnya, nilai Modulus Young batang aluminium dapat ditentukan dari gradien grafik hubungan antara frekuensi alami dengan satu per kuadrat panjang batang aluminium yang berdasar pada persamaan (1). 


\section{HASIL DAN PEMBAHASAN}

Batang aluminium yang digunakan mempunyai tebal $d=(0,90 \pm 0,01) \times 10^{-3} \mathrm{~m}$ dan massa jenis $\rho=(2,68 \pm 0,02) \times 10^{3} \mathrm{~kg} / \mathrm{m}^{3}$. Pengukuran frekuensi resonansi dilakukan untuk batang aluminium dengan panjang $l=0,3 \mathrm{~m} ; 0,35 \mathrm{~m} ; 0,4 \mathrm{~m} ; 0,45 \mathrm{~m}$; dan $0,5 \mathrm{~m}$. Berdasarkan pengamatan, getaran batang aluminium dengan panjang $l=0,3 \mathrm{~m}$ menghasilkan gelombang yang bentuknya mengikuti bentuk lenturan batang cantilever menurut Euler Bernouli pada keadaan dengan frekuensi resonansi $f_{2}$ (gambar 1b). Hasil pengamatan gelombang yang terbentuk untuk getaran batang aluminium dengan panjang $0,3 \mathrm{~m}$ dan tambahan magnet bermassa 2,3 g ditunjukkan pada gambar 3 .

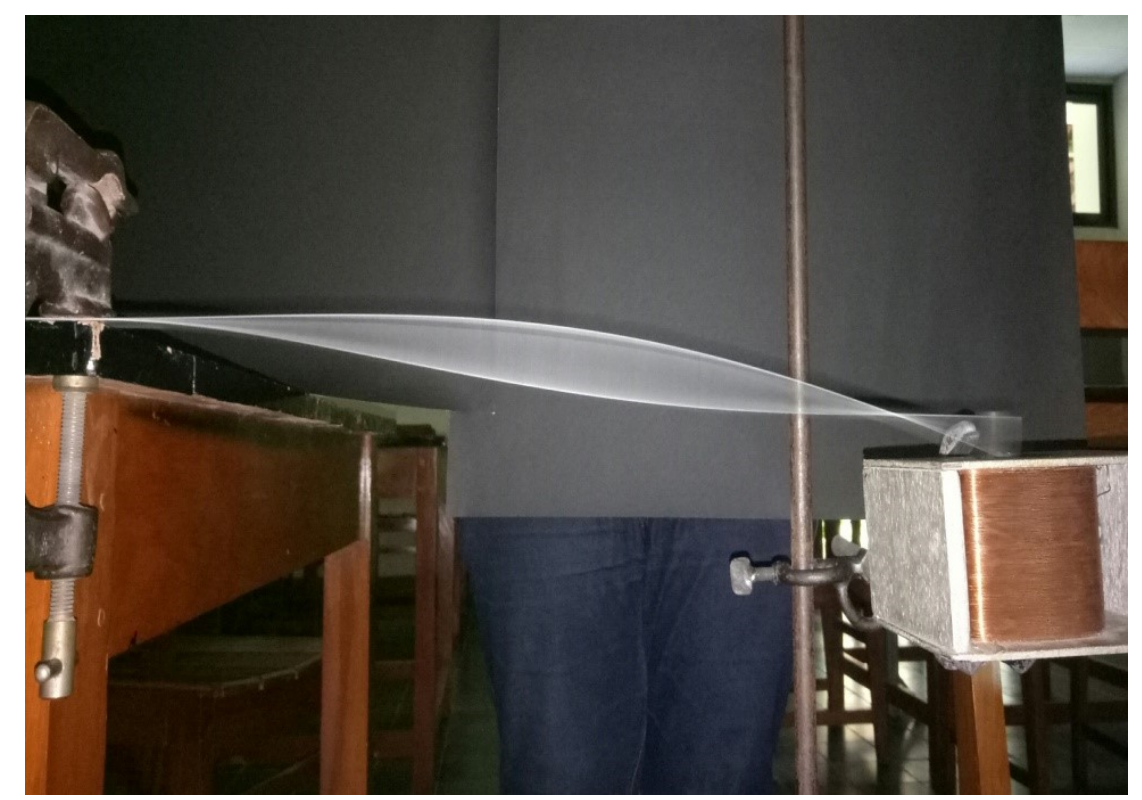

Gambar 3 Pola gelombang getaran batang aluminium untuk $l=0,3 \mathrm{~m}$; dengan magnet bermassa $2,3 \mathrm{~g}$

Untuk lebih mengecek bahwa keadaan tersebut merupakan keadaan pada $f_{2}$ dilakukan pengukuran panjang gelombang yang dihasilkan. Dari gambar 3 dapat ditentukan nilai setengah panjang gelombang. Selanjutnya pengukuran panjang $\lambda$ menggunakan aplikasi ImageMeter menghasilkan $\lambda=0,483 \mathrm{~m}$. Sesuai persamaan (3) untuk batang dengan panjang $0,3 \mathrm{~m}$, nilai frekuensi resonansi $f_{2}$ adalahn $0,48 \mathrm{~m}$. Nilai hasil pengukuran mendekati nilai teori sehingga frekuensi resonansi yang diukur pada eksperimen ini untuk panjang batang aluminium $l=0,3 \mathrm{~m}$ dituliskan dan dianalisis sebagai $f_{2}$. Hasil pengukuran frekuensi resonansi untuk panjang batang aluminium $l=0,3 \mathrm{~m}$ disajikan pada tabel 1 . 
Tabel 1 Hubungan frekuensi resonansi dengan massa magnet yang ditambahkan, untuk panjang $l=0,3 \mathrm{~m}$

\begin{tabular}{ccccccccc}
\hline No & $\begin{array}{c}\text { Massa } \\
\text { magnet, } \Delta m \\
\left(\times 10^{-3} \mathrm{~kg}\right)\end{array}$ & 1 & 2 & 3 & 4 & 5 & 6 & $\overline{f_{2}^{\prime}}(\mathrm{Hz})$ \\
\hline 1 & 2,3 & 44,5 & 44,5 & 44,5 & 44,5 & 44,5 & 44,5 & 44,5 \\
2 & 4,7 & 42,5 & 42 & 42 & 42 & 41,5 & 42 & 42 \\
3 & 6,8 & 41 & 40,5 & 40,5 & 40,5 & 41 & 41 & 40,75 \\
4 & 9,5 & 40 & 40 & 40 & 39,5 & 39,5 & 40 & 39,83 \\
5 & 11,4 & 39,5 & 39,5 & 39,5 & 39 & 39 & 39,5 & 39,33 \\
6 & 14,1 & 38,5 & 38,5 & 38,5 & 38,5 & 38,5 & 38,5 & 38,5 \\
\hline
\end{tabular}

Dari data hubungan frekuensi resonansi dengan massa magnet yang ditambahkan untuk panjang $l=0,3 \mathrm{~m}$, dibuat grafik frekuensi resonansi terhadap massa magnet yang ditambahkan seperti yang ditunjukkan pada gambar 4 .

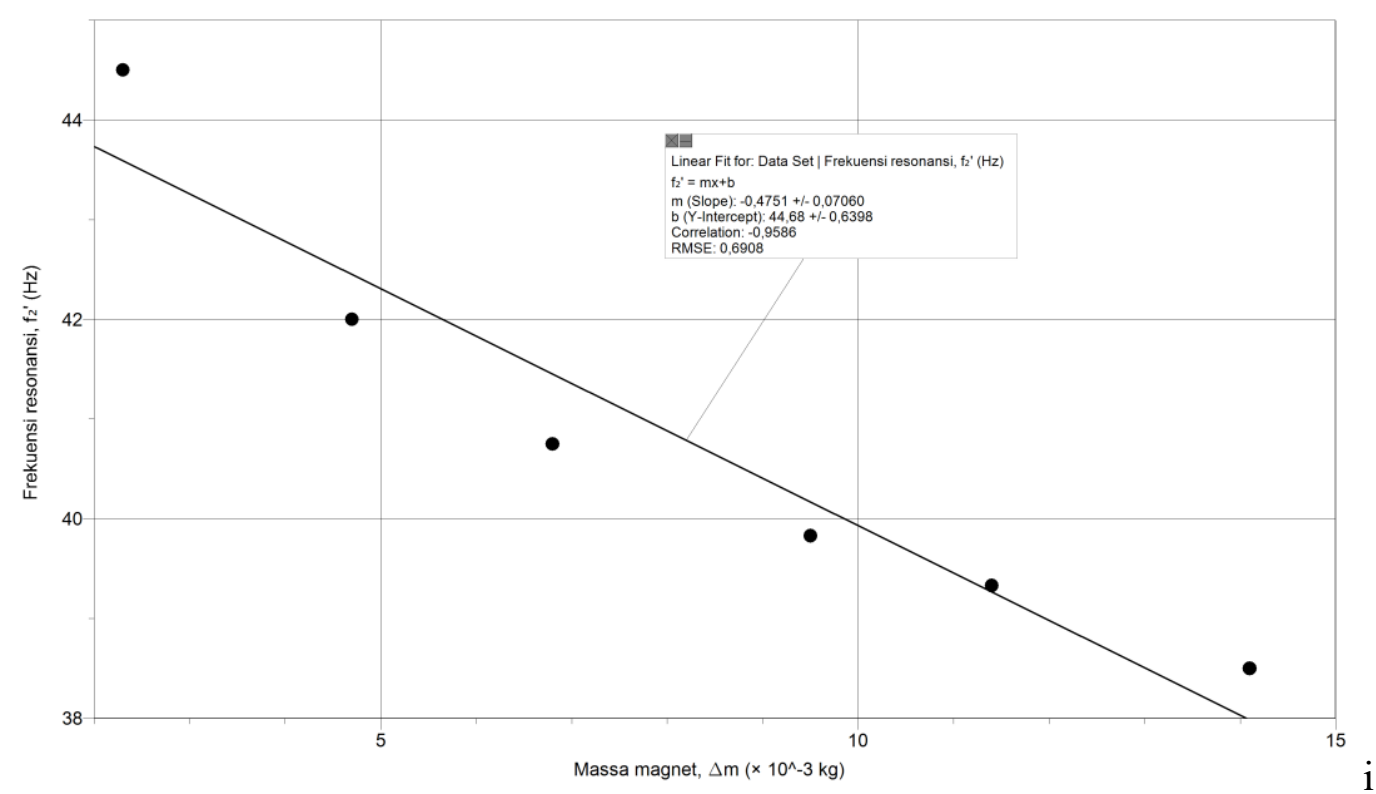

Gambar 4 Grafik hubungan frekuensi resonansi dengan massa magnet yang ditambahkan, untuk panjang $l=0,3 \mathrm{~m}$

Frekuensi alaminya diperoleh dari nilai perpotongan grafik dengan sumbu tegak, yaitu $f_{2}=44,7 \pm 0,6 \mathrm{~Hz}$. Dengan cara yang sama penentuan frekuensi alami juga dilakukan untuk panjang batang aluminium yang lain. Hasil pengukuran frekuensi alami untuk panjang batang aluminium yang lain disajikan pada tabel 2 .

Tabel 2 Hubungan antara frekuensi alami dengan panjang batang aluminium

\begin{tabular}{ccc}
\hline No & $l(\mathrm{~m})$ & $f_{2}(\mathrm{~Hz})$ \\
\hline 1 & 0,3 & $44,7 \pm 0,6$ \\
2 & 0,35 & $32,9 \pm 0,5$ \\
3 & 0,4 & $25,6 \pm 0,4$ \\
4 & 0,45 & $20,1 \pm 0,4$ \\
5 & 0,5 & $16,6 \pm 0,3$ \\
\hline
\end{tabular}


Dari tabel 2, nilai Modulus Young aluminium dapat ditentukan dari gradien grafik hubungan frekuensi alami terhadap satu per kuadrat panjang batang aluminium seperti yang disajikan dalam gambar 5. Penentuan nilai ini berdasar pada persamaan (1).

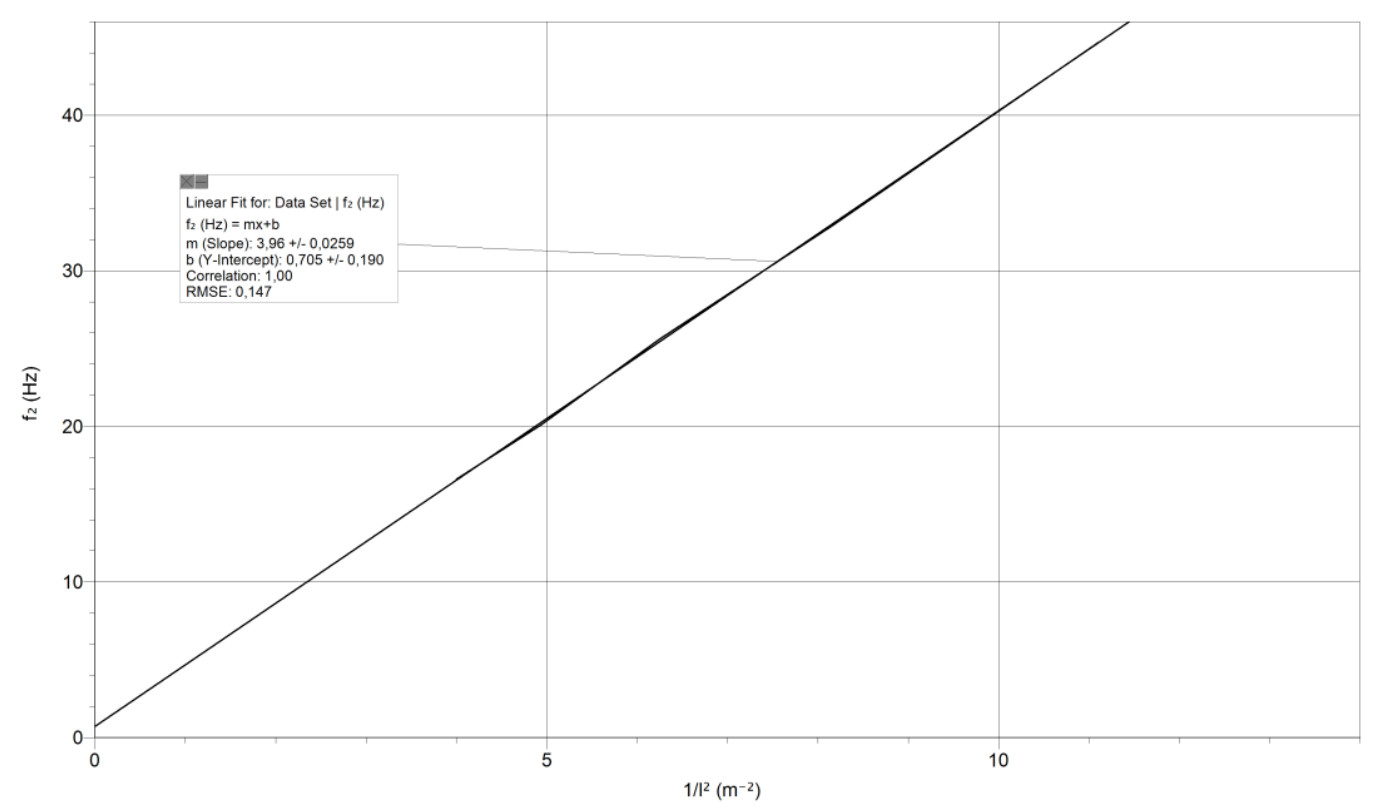

Gambar 5 Grafik hubungan $f_{2}$ terhadap $1 / l^{2}$

Dengan nilai gradien grafik yang diperoleh $p=(3,96 \pm 0,03) \mathrm{Hz} \mathrm{m}^{2}$ dan nilai $\beta_{2} \approx 4,7$; nilai Modulus Young aluminium dapat dihitung sebagai berikut.

$$
\begin{aligned}
& Y=\frac{48 \pi^{2} \cdot p^{2} \cdot \rho}{\left(\beta_{2}\right)^{4} \cdot d^{2}} \\
& Y=\frac{48 \pi^{2} \times\left(3,96 \mathrm{~Hz} \mathrm{~m}^{2}\right)^{2} \times\left(2,68 \times 10^{3}\right) \mathrm{kg} / \mathrm{m}^{3}}{(4,7)^{4} \times\left(0,9 \times 10^{-3} \mathrm{~m}\right)^{2}} \\
& Y=(5,04 \pm 0,03) \times 10^{10} \mathrm{~N} / \mathrm{m}^{2}
\end{aligned}
$$

Nilai Modulus Young batang aluminium yang diperoleh dari eksperimen ini mendekati nilai Modulus Young standar untuk aluminium yaitu $7,0 \times 10^{10} \mathrm{~N} / \mathrm{m}^{2}$. [Young dan Freedman, 2003]

Tujuan penelitian ini adalah untuk menentukan nilai Modulus Young aluminium dengan metode yang sederhana namun tidak merusak bahan sehingga dapat digunakan untuk keperluan pembelajaran. Pada penelitian ini digunakan batang aluminium berbentuk balok tipis dengan perbandingan panjang dan tebal lebih dari 10 kali sesuai dengan syarat yang berlaku menurut Euler-Bernouli. Batang alumunium dijepitkan pada sebuah meja secara horisontal pada salah satu ujungnya, sedangkan ujungnya yang lain dibiarkan bebas, sehingga memungkinkan bagian yang bebas tersebut dapat bergetar secara vertikal. Pada ujung bagian batang yang bebas dilekatkan sebuah magnet kecil untuk membuat batang aluminium bergetar pada sebuah medan magnet yang berubah terhadap waktu.

Keadaan resonansi akan dicapai ketika frekuensi medan magnet yang diatur sama dengan frekuensi alami getar batang aluminium dan magnet yang ditambahkan. Pengaturan frekuensi medan magnet kumparan harus diatur secara perlahan karena sedikit perubahan saja dapat 
sangat mempengaruhi besar amplitudo dan membuat getaran tidak dalam keadaan tunak. Pengukuran frekuensi resonansi dilakukan sebanyak enam kali untuk mengatasi masalah tersebut. Gelombang yang terbentuk pada keadaan resonansi harus berada dalam keadaan konstan untuk frekuensi yang diatur dan getaran yang terjadi stabil. Pada gambar 3, terlihat pula bahwa bentuk gelombang yang dihasilkan dari getaran batang aluminium tidak sempurna jika dibandingkan dengan bentuk gelombang berdiri pada tali. Simpul pada bagian batang yang dijepit tidak berada tepat pada pangkal batang aluminium tetapi sedikit bergeser dari pangkal batang aluminium. Hal tersebut terjadi karena sifat batang aluminium yang lebih kaku dari pada tali.

Frekuensi alami dari batang aluminium yang bergetar ditentukan dari grafik hubungan antara frekuensi resonansi dengan massa magnet yang ditambahkan. Seperti yang terlihat pada grafik pada gambar 4, titik-titik koordinat yang ada tidak tepat berhimpit pada garis. Walaupun pengukuran frekuensi resonansi telah dilakukan sebanyak enam kali, namun tetap memberikan hasil pengukuran yang sama. Setiap titik koordinat yang ada berpengaruh besar terhadap hasil penentuan nilai frekuensi alami batang aluminium. Hal tersebut dapat dipandang bahwa penambahan magnet di bagian ujung batang aluminium telah mengubah massa jenis sistem itu sendiri dan membuat batang aluminium menjadi tak homogen di setiap bagiannya. Itulah yang membuat adanya selisih nilai Modulus Young batang aluminium yang diperoleh dari eksperimen dengan nilai Modulus Young aluminium standar. Namun, hasil tersebut tetap memiliki orde yang sama yaitu pada orde $10^{10} \mathrm{~N} / \mathrm{m}^{2}$.

Penelitian menentukan nilai Modulus Young dengan analisis keadaan resonansi sebuah batang aluminium yang bergetar ini menggunakan alat dan bahan yang sederhana dan mudah diperoleh di laboratorium. Rangkaian alat, prosedur percobaan, dan pengamatan eksperimen ini sederhana dan tidak memerlukan alat bantu khusus seperti sensor. Untuk menganalisis data pun cukup menggunakan aplikasi Logger Pro sehingga dapat digunakan dalam pembelajaran. Penelitian ini dapat digunakan sebagai referensi untuk eskperimen pengukuran Modulus Young untuk mengatasi kelemahan metode yang dapat merusak bahan saat melakukan pengukuran. Penggunaan aplikasi ImageMeter untuk mengukur panjang $\lambda$ membantu untuk menunjukkan telah dicapainya keadaan resonansi dari batang aluminium yang bergetar. Pengukuran panjang $\lambda$ pada penelitian ini karena tidak dapat dilakukan secara langsung batang aluminium dalam keadaaan bergerak sehingga sulit untuk dilakukan dan juga karena adanya resiko terkena arus listrik di daerah sekitar kumparan. Eksperimen ini menunjukkan suatu keadaan resonansi dari batang aluminium yang bergetar yang tidak biasa ditemui dalam pembelajaran fisika. Konsep getaran paksa yang diterapkan untuk mengatasi adanya redaman pada getaran membuat pengamatan pada penelitian ini tidak dibatasi oleh waktu sehingga menjadi hal yang menarik untuk pembelajaran.

Selain itu, adanya berbagai konsep fisika yaitu getaran paksa, gelombang, resonansi, kelistrikkan dan kemagnetan yang dibahas dalam penelitian pengukuran Modulus Young aluminium dan dijelaskan keterkaitan antara satu konsep dengan konsep yang lain tersebut, penelitian ini dapat dijadikan acuan bagi guru mengenai metode pembelajaran fisika konstruktivisme dan bagaimana menjelaskan berbagai konsep dalam suatu peristiwa fisika.

\section{KESIMPULAN}

Nilai Modulus Young aluminium dapat ditentukan melalui pengukuran terhadap frekuensi resonansi untuk batang aluminium yang bergetar. Keadaan resonansi batang aluminium dapat ditunjukkan dengan mengukur panjang $\lambda$ dari gelombang yang dihasilkan menggunakan aplikasi Image Meter. Dari eksperimen ini diperoleh nilai Modulus Young aluminium adalah $Y=(5,04 \pm 0,03) \times 10^{10} \mathrm{~N} / \mathrm{m}^{2}$. Metode yang digunakan dalam eksperimen ini dapat 
digunakan sebagai acuan untuk kepentingan pembelajaran misalnya untuk menentukan nilai Modulus Young suatu bahan dengan analisis keadaan resonansi suatu batang yang bergetar.

\section{SARAN}

Berdasarkan pengalaman melakukan penelitian ini, beberapa saran untuk pengembangan penelitian sejenis menentukan nilai Modulus Young suatu bahan adalah:

- Pengukuran Modulus Young batang aluminium menggunakan metode dinamis dengan analisis getaran lenturnya dapat menjadi suatu referensi eksperimen yang relevan untuk pembelajaran karena tergolong sederhana, tidak mahal namun teliti akurat dan tidak merusak bahan yang digunakan, serta dapat mengatasi kelemahan metode statis yang ada.

- Satu hal penting yang perlu diperhatikan sebelum melakukan penelitian ini adalah memprediksi terlebih dahulu panjang minimal dari batang aluminium yang dapat melentur menghasilkan bentuk gelombang. Selain panjang minimal, perlu juga diprediksikan panjang maksimum dari batang aluminium yang digunakan oleh karena AFG yang digunakan memiliki frekuensi minimal yaitu $10 \mathrm{~Hz}$.

\section{DAFTAR PUSTAKA}

Apriati, Yosephine Novita. 2017. Peluruhan pada Ketinggian Air di dalam Tabung Sebagai Model Peluruhan Bahan Radioaktif yang Diamati dengan Menggunakan Rekaman Video. (Skripsi S1,: Universitas Sanata Dharma, 2017).

Murray, John.1982. Practical Physics in SI. Hong Kong: Wing King Tong Co Ltd.

Pradan R, A K Dhara, P Panchadhyayee, dan D Syam. 2015. "Determinaton of Young's modulus by studying the flexural vibration of a bar: experimental and theoretical approaches". Europan Journal of Physics. Vol. 37, No. 10.1088/01430807/37/1/015001

Rao, Singiresu S. 2007. Vibration of Continuous Systems. Canada: John Wiley \& Sons, Inc.

Sahu, Gregorius Adirahmat. 2017. Pengukuran Modulus Young Stainless Steel dengan Analisis Getaran Menggunakan Force Sensor. (Skripsi S1,: Universitas Sanata Dharma, 2017).

Thomson, William T dan Lea Prasetyo. 1992. Teori Getaran dengan Penerapan (Edisi II). Jakarta: Penerbit Erlangga.

Young, Hugh D dan Roger A Freedman. 2003. Fisika Universitas Edisi Kesepuluh Jilid 2. Jakarta. Penerbit Erlangga. 